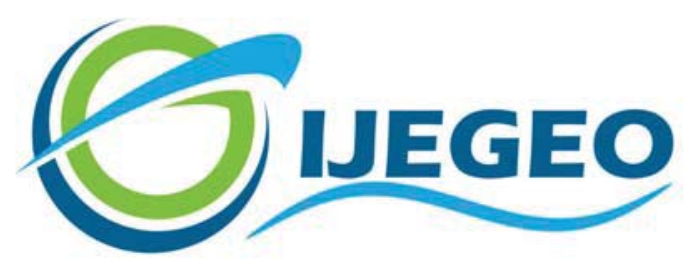

International Journal of Environment and Geoinformatics (IJEGEO) is an international, multidisciplinary, peer reviewed, open access journal.

\title{
A Comparative MCDM Analysis of Potential Short-Term Measures for Dealing with Mucilage Problem in the Sea of Marmara
}

\section{Başak SAVUN HEKIMOĞLU, Barbaros ERBAY, Z. Selmin BURAK, Cem GAZİĞ́LU}

\author{
Chief in Editor \\ Prof. Dr. Cem Gazioğlu \\ Co-Editors
}

Prof. Dr. Dursun Zafer Şeker, Prof. Dr. Şinasi Kaya,

Prof. Dr. Ayşegül Tanık and Assist. Prof. Dr. Volkan Demir

Editorial Committee (December 2021)

Assoc. Prof. Dr. Abdullah Aksu (TR), Assit. Prof. Dr. Uğur Algancı (TR), Prof. Dr. Bedri Alpar (TR), Assoc. Prof. Dr. Aslı Aslan (US), Prof. Dr. Levent Bat (TR), Prof. Dr. Paul Bates (UK), İrşad Bayırhan (TR), Prof. Dr. Bülent Bayram (TR), Prof. Dr. Luis M. Botana (ES), Prof. Dr. Nuray Çağlar (TR), Prof. Dr. Sukanta Dash (IN), Dr. Soofia T. Elias (UK), Prof. Dr. A. Evren Erginal (TR), Assoc. Prof. Dr. Cüneyt Erenoğlu (TR), Dr. Dieter Fritsch (DE), Prof. Dr. Çiğdem Göksel (TR), Prof.Dr. Lena Halounova (CZ), Prof. Dr. Manik Kalubarme (IN), Dr. Hakan Kaya (TR), Assist. Prof. Dr. Serkan Kükrer (TR), Assoc. Prof. Dr. Maged Marghany (MY), Prof. Dr. Michael Meadows (ZA), Prof. Dr. Nebiye Musaoğlu (TR), Prof. Dr. Masafumi Nakagawa (JP), Prof. Dr. Hasan Özdemir (TR), Prof. Dr. Chryssy Potsiou (GR), Prof. Dr. Erol Sarı (TR), Prof. Dr. Maria Paradiso (IT), Prof. Dr. Petros Patias (GR), Prof. Dr. Elif Sertel (TR), Prof. Dr. Nüket Sivri (TR), Prof. Dr. Füsun Balık Şanlı (TR), Prof. Dr. Uğur Şanlı (TR), Duygu Ülker (TR), Prof. Dr. Seyfettin Taş (TR), Assoc. Prof. Dr. Ömer Suat Taşkın (TR), Assist. Prof. Dr. Tuba Ünsal (TR), Dr. Manousos Valyrakis (UK), Dr. İnese Varna (LV), Dr. Petra Visser (NL), Prof. Dr. Selma Ünlü (TR), Assoc. Prof. Dr. Oral Yağcı (TR), Prof. Dr. Murat Yakar (TR), Assoc. Prof. Dr. İ. Noyan Yılmaz (AU); Assit. Prof. Dr. Sibel Zeki (TR) 


\title{
A Comparative MCDM Analysis of Potential Short-Term Measures for Dealing with Mucilage Problem in the Sea of Marmara
}

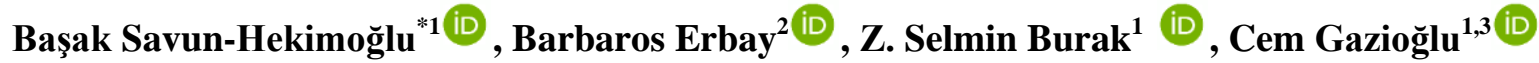

${ }^{1}$ Istanbul University, Institute of Marine Sciences and Management, Department of Marine Environment, 34134 Vefa İstanbul/Turkey

${ }^{2}$ AY-RA Construction and Mining Limited Company, Trabzon/Turkey

${ }^{3}$ Istanbul University, Faculty of Architecture, İstanbul/Turkey

* Corresponding author: B.Savun Hekimoğlu

Received: 19.09 .2021

E-mail: basak.savun@istanbul.edu.tr

How to cite: Savun-Hekimoğlu,et al., C. (2021). A Comparative MCDM Analysis of Potential Short-Term Measures for Dealing with Mucilage Problem in the Sea of Marmara, International Journal of Environment and Geoinformatics (IJEGEO), 8(4):572-580, doi. 10.30897/ ijegeo. 1026107

\begin{abstract}
Mucilage is a dense and highly viscous substance made up of extracellular polysaccharides produced and secreted by the overgrowth of various aquatic species. Rising ocean temperatures, as well as human-induced stressors like inadequate treatment levels and overfishing, are common causes of such algal blooms. By mid-2020, the Sea of Marmara was covered with mucilage that threatens marine life, tourism, fisheries and the economy. Even though this was not the first mucilage outbreak in the Sea of Marmara and was not a region-specific occurrence, it was one of the worst. The phenomenon attracts increasing attention as it severely impacts the overall ecology, particularly benthic creatures. This study aims to evaluate the short-term strategies that can be used to control mucilage in the Marmara Sea according to environmental, economic, technological, technical and social criteria. It is important to note that although integrating conventional treatment plants with advanced nutrient treatment technologies is the long-term and ultimate solution to the issue; this study focuses only on short-term measures to control a mucilage outbreak in the Sea of Marmara. Fuzzy Theory is used to analyze data obtained from experts from various sectors using two separate Multi Criteria Decision Making (MCDM) models: Preference Ranking Organization Method for Enrichment Evaluations (PROMETHEE) and Technique for Order of Preference by Similarity to Ideal Solution (TOPSIS). The results indicate that stopping fishing is the best alternative, whereas collecting mucilage on the surface is the second-best preferable by two methods (F-TOPSIS, F-PROMETHEE). According to experts, the third option is to use beneficial bacteria to eliminate mucilage, while reactive oxygen dosing is the least appealing option.
\end{abstract}

Keywords: Mucilage, Multi Criteria Decision Making, the Sea of Marmara, TOPSIS, PROMETHEE

\section{Introduction}

Since May 2021, residents of coastal cities in Turkey along the Marmara Sea have been concerned about thick layers of foam on beaches and in harbors. The material is found naturally in the Sea of Marmara and worldwide, but this is the first time it has been observed in Turkey on such a large scale (Savun-Hekimoğlu and Gazioğlu, 2021; Uğur et al., 2021; Kavzoğlu et al., 2021). Figure 1 illustrates the extent of this environmental catastrophe. The image was taken during a site investigation by the Istanbul University Institute of Marine Sciences and Management in the Sea of Marmara using the R/V Alemdar II Research Vessel. The water was covered in a layer of marine mucilage, also known as "sea snot," which has attracted the world's attention.

Marine mucilage is a mucus-like organic material released into the water when phytoplankton proliferates in response to environmental conditions (Danovaro et al., 2009). Structurally, mucilage is a harmless organic material, but studies have shown that it creates an ideal environment for microorganisms such as bacteria and viruses, and therefore organisms, including harmful organisms, cluster on mucilage (Danovaro et al., 2009; Precali et al., 2005; Del Negro et al., 2005). Danovaro et al. (2009) investigated the microbial diversity and disease spreading potential of the mucilage and observed that the mucilage contains a wide microbial diversity and pathogenic species not found in the surrounding seawater. Although multiple causes of marine mucilage have been identified, the production mechanism remains unclear to this day (Funari and Ade, 1999; Giani et al., 2005; Kraus and Supic, 2015). Climate change, anthropogenic pressures, and variations in nutrient concentrations in the sea are all abiotic causes, and the microbial response to these external situations is the outcome of biotic factors (Cozzi et al., 2004; Malej et al., 2003).

Among the various mechanisms that could be involved in mucilage formation processes, the following can be specifically listed (Danovaro et al., 2009):

1. The release and leakage of carbohydrates produced as excess primary production (photosynthesis) by phytoplankton under stress conditions into the marine environment (polysaccharides produced in high amounts by diatoms in P-constrained conditions),

2. Death and cell fragmentation, as well as the mixing of structural polysaccharides from cell wall residues into the marine environment, 
3. Cellular contents comprising substantial volumes of dissolved organic matter (DOM) and polysaccharides are mixed into the marine environment as a result of death and cell fragmentation/lysis

4. Accumulation of high molecular weight organic compounds/polymers over time due to limited bacterial hydrolysis and biodegradation,

5. Mixing and accumulation of organics in the cell contents into seawater as a result of viral infection and cell lysis of prokaryotes and phytoplankton in the presence of viruses.

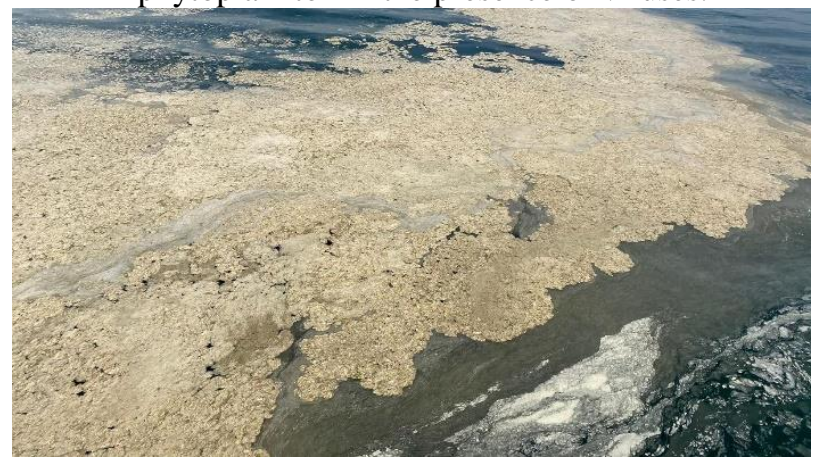

Fig. 1. Mucilage in the Sea of Marmara

Mucilage formations in the oceans are not really a new phenomenon; they were first detected off the coast of Italy in 1729 (Bianchi, 1746). The fact that the mucilage event took place in 1729 clearly shows that sea pollution cannot be a single cause (Rinaldi and Vollenwider, 1995). This global phenomenon occurs regularly in several coastal places. It has occurred in the Mediterranean Sea, West Japan's Ariake Sound, New Zealand's Tasman Bay, and near the Pacific coast of the United States. The first scientific description of mucilage was made in 1872, and all subsequent observations were reported (Umani et al., 1989). In November of 2020, marine mucilage formed on the surface of the Sea of Marmara and gradually expanded until mid-2021 (Acar et al. 2021; Özalp, 2021). A detailed literature review on the mucilage problem in semi-enclosed seas, especially in the Marmara Sea, was conducted by SavunHekimoğlu and Gazioğlu (2021). Studies have also been conducted on the chemical characterization of mucilage under changing environmental conditions (Aksu et al., 2021), the vertical distribution of its typology in the water column (Öztürk et al., 2021), and the phytoplankton composition and physicochemical conditions that are effective in its formation (Ergül et al., 2021).

The Sea of Marmara is a 2-layered sea between the Black Sea and the Aegean Sea (Mediterranean). Saline water from the Mediterranean forms the lower layer, and brackish waters from the Black Sea form the upper layer. The volume of water flowing from the Black Sea affects circulation in the Sea of Marmara. The water flow from the Strait of Istanbul (Bosphorus) into the Sea of Marmara is maximum in June and lowest in October. Hence, the sea conditions have stabilized by the end of October, and mucilage formation can begin if the other conditions are also favorable (Beşiktepe, et al., 1994;
Balkıs-Özdelice et al., 2020; Altık and Kayışoğlu, 2015). Furthermore, over the last 20 years, the water temperature in Marmara has risen by 2 to 2.5 degrees Celsius, well above the global norm. Balıkesir, Bursa, Çanakkale, İstanbul, Kocaeli, Tekirdağ and Yalova provinces discharge their wastewater into the Sea of Marmara (Burak et al., 2021). More than half of these discharges pass through pre-treatment a process, which includes only physical treatment, constitutes a significant part of the urban pollution load in the sea (Öztürk et al., 2021). The daily discharge to the Sea of Marmara is 6.9 million cubic meters per day, and its distribution by cities is given in Figure 2 (Öztürk et al., 2021).

The Ministry of Environment and Urbanization released a 22-article action plan to address the mucilage problem in early June. In order to successfully reduce nitrogen and phosphorus, existing treatment plants should be integrated with advanced treatment technologies. Because the region has over 100 deep-sea discharge stations, advanced treatment systems are critical. Furthermore, a larger emphasis on the reuse of treated wastewater is being proposed. The streams that transport agricultural pesticides to the sea will be monitored on a regular basis under the action plan (Topçu et al., 2021). Although there is no mucilage visible on the surface at the moment, we know that it is found in deep waters, sinking to the bottom. Therefore, it remains essential to develop short and long-term solutions to the problem. The sea's surface was cleared by the end of August, but there's still "sea snot" in the sea bottom. Furthermore, because the origins of mucilage have not been removed, scientists warn that it may reappear on the surface in the following months.

Multi Criteria Decision Making (MCDM) approaches ar e used for a complete evaluation of short-term managem ent solutions due to the variability of the criteria set nece ssary for pollution prevention challenges. One of the mo st well-known features of MCDM approaches is their fle xibility to include several sorts of criteria (Savun-Hekim oğlu et al., 2021; Sulemana et al., 2020; Mohammadı, an d Hosseinal1, 2019). Some evaluation criteria are quantit ative and can be easily integrated into optimization mode 1s, while others, such as public acceptance and environm ental friendliness, are impossible to quantify. Expert eval uations of five different water short-term measures with $r$ espect to seven criteria are used to evaluate the alternativ es. Following that, the evaluations are handled using fuz zy logic with two MCDM methodologies: Technique for Order Performance by Similarity to Ideal Solution (TOP SIS) and Preference Ranking Organization Method for E nrichment Evaluations (PROMETHEE).

The key reason for choosing TOPSIS is that the method $\mathrm{i}$ s unaffected by criteria correlation, which could be a con cern in our circumstances. TOPSIS also has a straightfor ward framework that decision-makers may simply under stand (Behzadian et al., 2012). Its suitability drives PRO METHEE for a wide range of factors, such as cost, effici ency, and public acceptance. Furthermore, PROMETHE E's results can be properly visualized. 


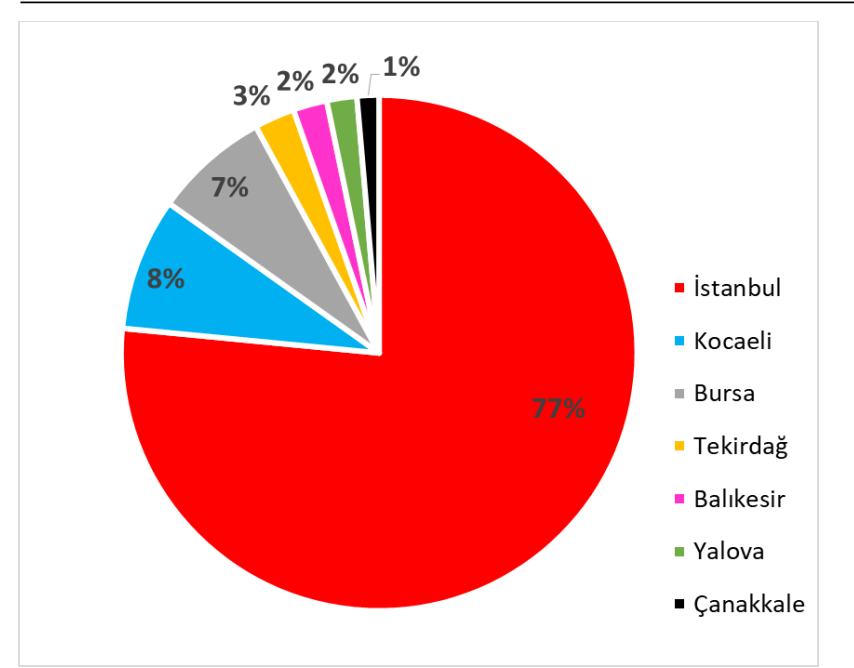

(a)

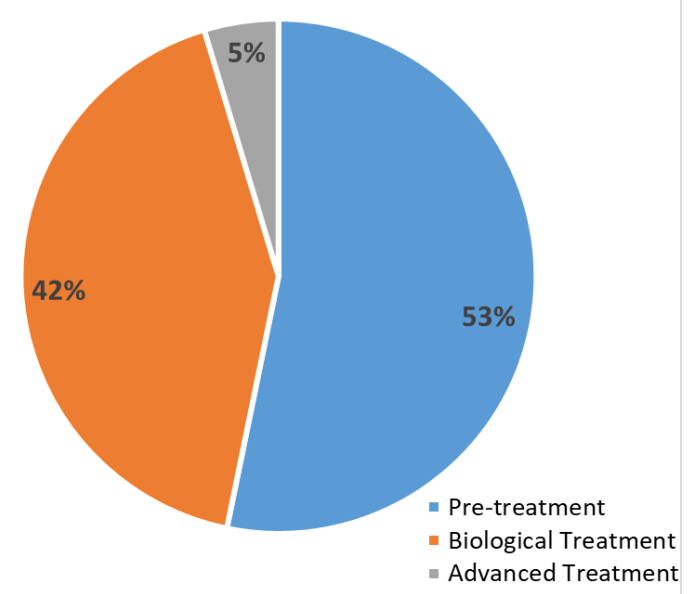

(b)

Fig.2 . Discharges to the Sea of Marmara (a) Distribution by cities (b) Treatment levels (Öztürk et al., 2021).

TOPSIS with linear normalization is considered as an efficient outranking method compared to other methods in the literature. TOPSIS's Euclidean metric yields result comparable to VIsekriterijumsko KOmpromisno Rangiranje (VIKOR), which uses a general Lp metric and more calculation coefficients (Opricovic and Tzeng, 2004). TOPSIS outputs with vector normalization have been shown to be more realistic and stable.

This study aims to evaluate various short-term solution alternatives for mucilage problem. This study contributes to the MCDM literature by providing a solution ranking for short-time measures to control mucilage issue in the Sea of Marmara. The findings may be useful for city planners and policymakers. To the best of our knowledge, this is the first study utilizing MCDM methodologies for a mucilage outbreak. Hence, future researchers who are interested in these methodologies may benefit from this approach.

\section{Materials and Methods}

Figure 3 depicts an overview of the study's methodology. The determination of alternatives and selecton of evaluation criteria is the first step in this MCDM study, followed by creating evaluation forms and scales. The data was collected from a distinct expert group using these forms, including top administrators from governmental organizations, respected academics and private-sector executives. The evaluations are then processed using two separate MCDM approaches, TOPSIS and PROMETHEE, using fuzzy sets to produce preference rankings of options based on evaluation criteria. The development of alternatives, the determination of criteria, data gathering, and data processing are all phases of MCDM analyses (Fig. 3). All of these phases are described in detail in the subsections that follow.

\section{Development of Alternatives}

Increased temperatures, the stagnant condition of the water, and the nutrient load released into the sea are all variables that cause mucilage, as previously stated. As changing environmental conditions is impossible, the best option is to avoid pollutant discharge into the sea. Integrating conventional treatment plants with advanced treatment processes is the long-term and final solution to this issue. On the other hand, several short-term solutions to the mucilage issue in the Sea of Marmara must be evaluated and are included below:

- $\quad$ Stop fishing: The primary food source of fish is the single-celled organisms that produce the mucilage. As a result, temporarily ceasing fishing activities may result in an increase in fish population leading to the natural removal of mucilage.

- The use of beneficial bacteria: Utilization of local bacterial isolates obtained from the seas for 20 years to the mucilage-covered region to eliminate mucilage with beneficial bacteria.

- Oxygen Dosing: This alternative suggests that injecting reactive oxygen produced with cold atmospheric plasma into seawater will solve the mucilage problem. Reactive oxygen dosing via mobile platforms is based on measuring mucilage's temporal and spatial distribution.

- Collecting mucilage on the surface: Within the scope of the cleaning activities, some provinces bordering the Sea of Marmara collected mucilage on the surface. The collected mucilage was then delivered to solid waste collection sites for disposal. Approximately 11 thousand tons of mucilage were collected as part of the mucilage collection activities.

\section{Development of Criteria}

The alternatives mentioned above are evaluated using seven criteria in this study. A thorough literature review was carried out on efforts to clean up mucilage prior to deciding on decision-making criteria. Then, using oneon-one discussions with experts in the field, the criteria were finalized. Table 1 lists seven decision-making criteria of five classes. 
Table 1. Criteria for evaluating alternative solutions.

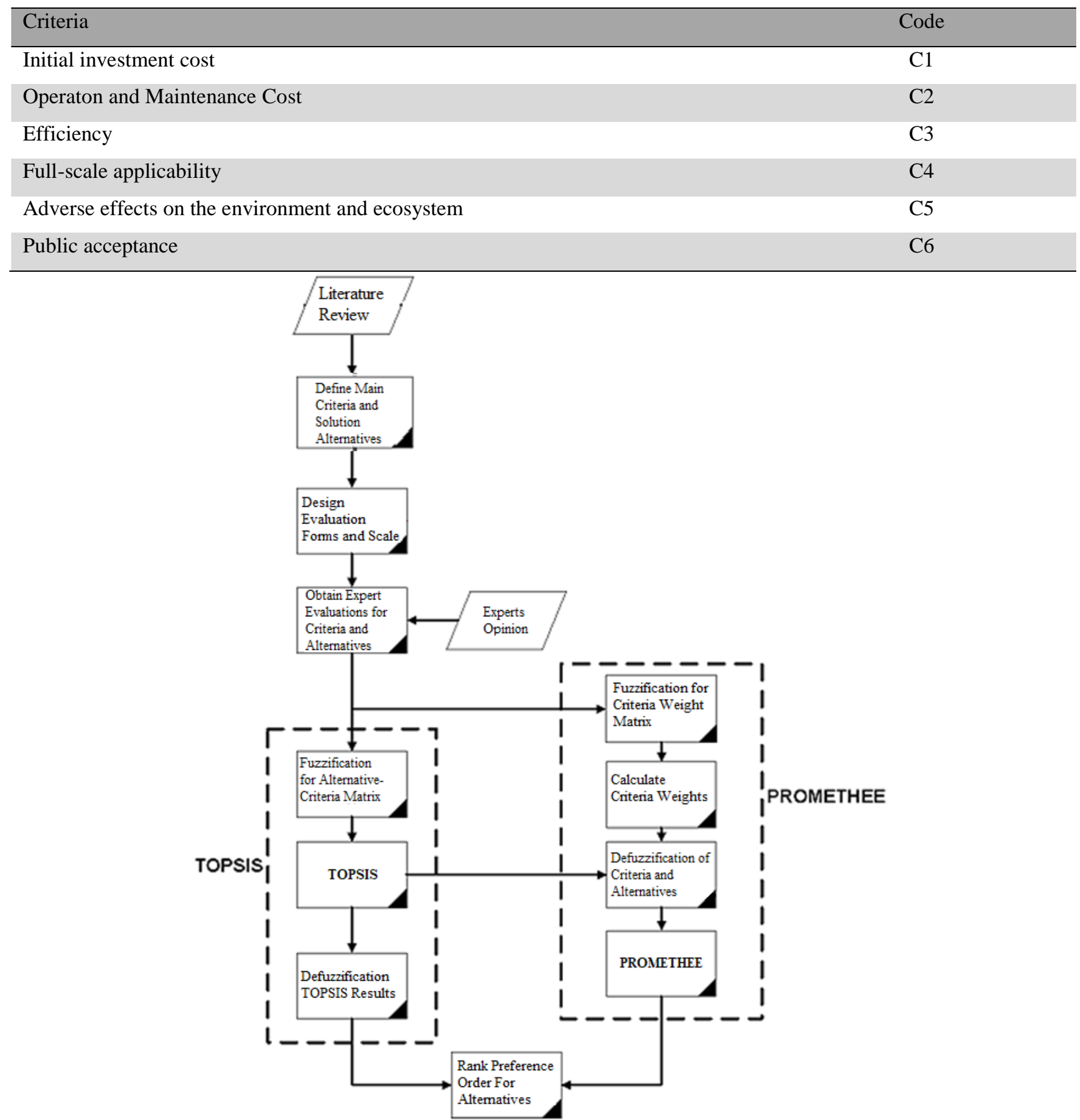

Fig. 3. Overview of the study.

Any infrastructure investment is evaluated based on its initial investment and operational costs (Coban et al., 2018). The activity's construction and operating phases may have a negative influence on the ecosystem. Land occupation, waste production, and ecological destruction are potential environmental risks (Kumar et al., 2017). As a result, any alternative solution should be evaluated in terms of both its risks and benefits. For solutions' long-term viability and reliability, efficiency is essential (Cambrainha and Fontana, 2018). Successful water management necessitates a thorough examination of both the physical and social components of water concerns. Institutions must establish recognition on a social and political level and responses to controversies and disputes because the engagement of the community, stakeholders, and government agencies is critical in mucilage management (Scholten et al., 2015).

It's important to note that some of the criteria refer to costs, while others focus on benefits and public welfare. TOPSIS and PROMETHEE algorithms are used to address the heterogeneity in the criteria set. While calculating alternative rankings, minimization was applied for costs and maximization for benefits. As a result, the potential detrimental impacts of employing contradictory criteria on the results are avoided. 


\section{Calculation of criteria weights}

The weights of the criteria listed in Table 2 are calculated using the F-TOPSIS approach. For fuzzification, we determine the parameters of a triangular distribution. In all MCDM approaches, these fuzzy parameters are employed as criteria weights to generate each alternative's importance score. Other methods for calculating criteria weight are suggested in the literature, such as AHP, Full Consistency Method (FUCOM), and Best Worst Method (BWM). Regarding the amount of data required, the method used in this study differs from the literature since it uses linguistic rankings rather than pairwise comparisons to compute criteria weights.

\section{Fuzzy-TOPSIS}

F-TOPSIS begins by converting linguistic rankings for each criterion into the triangular distribution's parameters. For each criterion, these distribution parameters are generalized to overall ratings. Similarly, experts' evaluations of each strategy in terms of each criterion are converted into numerical values. Using computed criteria weights, the weighted average of these distribution parameters is calculated and normalized. The best and worst ideal solutions are obtained using these normalized parameters, and the distances between each alternative are calculated using these distances. Closeness coefficients, which lead to preference rankings, are calculated using these distances.

\section{Fuzzy-PROMETHEE}

F-PROMETHEE begins by defuzzifying each evaluation by taking the triangular distribution's expectation. The preference values of each alternate pair with respect to each criterion are then determined, using a Gaussian preference function for each criterion. The difference between alternatives is mapped to the $[0,1]$ interval using this Gaussian preference function, which results in preference values. The weighted average of each preference value is then computed using the criteria weights, which are the expectation of the triangular distribution of each criteria evaluation in F-TOPSIS. The last two steps of F-PROMETHEE are the calculation of positive and negative ranking flows, the difference of which leads to the net outranking flow, which leads to preference rankings.

\section{Results and Discussion}

The calculated criteria weights obtained from F-TOPSIS are given in Table 2. The study's experts implicitly agree upon the importance of initial investment and operation and maintenance costs criteria. However, weights ascribed to other criteria have wider differences. Table 2 shows that expert opinion on the importance of C6, which is concerning public acceptance, varies significantly.

Table 3 shows a combination of the results of the two MCDM models. Prohibition of fishing is found to be the best option among the alternatives for both models due to its cost advantage and ease of implementation. Importantly the difference between this alternative with its closest rival is the largest among all differences. This indicates prohibition of fishing is considered to be the first policy to be implemented by the experts. Reactive oxygen dosing is ranked four by both models, which makes it the least appealing option. This is mainly due to its high cost and low implementability on a large scale. Considering that mucilage is a large-scale problem in most cases, efficiency and cost are the most important criteria for any solution (Table 2).

In the last mucilage instance in the Sea of Marmara, the collection of mucilage from on the surface is the first implemented policy, although it is ranked to be the second-best alternative. This selection is mainly due to the lower social impact of this alternative. This indicates that the importance of $\mathrm{C} 6$ might be much higher for public decisions.

Table 2. F-TOPSIS Criteria Weights

\begin{tabular}{|c|c|c|c|c|}
\hline Criteria & Code & Lower Bound & Median & Upper Bound \\
\hline Initial investment cost & $\mathrm{C} 1$ & 0.400 & 0.825 & 1.000 \\
\hline Operaton and Maintenance Cost & $\mathrm{C} 2$ & 0.500 & 0.850 & 1.000 \\
\hline Efficiency & $\mathrm{C} 3$ & 0.500 & 0.908 & 1.000 \\
\hline Full-scale applicability & $\mathrm{C} 4$ & 0.400 & 0.825 & 1.000 \\
\hline Adverse effects on the environment and ecosystem & $\mathrm{C} 5$ & 0.400 & 0.833 & 1.000 \\
\hline Public acceptance & C6 & 0.200 & 0.767 & 1.000 \\
\hline
\end{tabular}

Table 3. Results of MCDM Models

\begin{tabular}{|c|c|c|c|c|c|c|c|c|c|}
\hline \multirow[b]{2}{*}{ Alternatives } & \multirow[b]{2}{*}{ Code } & \multicolumn{4}{|c|}{ F-TOPSIS } & \multicolumn{4}{|c|}{ F-PROMETHEE } \\
\hline & & $\mathrm{d}^{*}$ & d- & Score(Cci) & Ranking & $\mathrm{Q}+$ & Q- & Q & Ranking \\
\hline Stop Fishing & A1 & 3.479 & 4.022 & 0.536 & 1 & 2.496 & 0.341 & 2.156 & 1 \\
\hline Eliminating mucilage with Beneficial Bacteria & $\mathrm{A} 2$ & 4.031 & 3.248 & 0.446 & 3 & 0.350 & 1.609 & -1.259 & 3 \\
\hline Reactive Oxygen Dosing & A3 & 4.142 & 3.186 & 0.435 & 4 & 0.415 & 1.730 & -1.316 & 4 \\
\hline Collecting mucilage on the surface & A4 & 3.837 & 3.508 & 0.478 & 2 & 1.069 & 0.651 & 0.419 & 2 \\
\hline
\end{tabular}




\section{Conclusion}

Mucilage outburst is a serious problem that has social and economic implications. Once this problem occurs, different solution alternatives need to be evaluated against multiple criteria consisting of qualitative and quantitative features. Heterogeneity of criteria requires the utilization of multi-criteria decision-making methods based on expert opinions, so those methods are widely used in the solution of environmental problems. In this study, a multi-criteria decision making method that can be applied to select a short-term strategy to control the mucilage problem in the Sea of Marmara is suggested. To this end, first the alternatives that can be applied and the criteria to evaluate these alternatives were determined. Afterwards, the weights of the criteria were determined with expert opinions, and then the alternatives were evaluated and ranked with respect to the criteria set. As a method, the results of Fuzzy TOPSIS and Fuzzy PROMETHEE methods were compared by integrating Fuzzy Logic with TOPSIS and PROMETHEE methods.

In this study, prohibition of fishing is found to be the best alternative, whereas collecting mucilage on the surface is the second-best preferable one by two method (F-TOPSIS, F-PROMETHEE). Although collecting mucilage seems to be a more suitable method in terms of applicability, it is revealed by multi-criteria decisionmaking methods that there is a better alternative when all criteria are taken into account. Eliminating mucilage with Beneficial Bacteria is the third method to be applied, while Reactive Oxygen Dosing is recommended as the last method to be applied among alternative applications.

\section{Acknowledgements}

The authors wish to express their gratitude to the Istanbul University Research Fund (BAP) for granting a post-doctoral scholarship to Başak Savun-Hekimoğlu with the identification number MAB-2019-34967. The authors would also like to thank the R/V Alemdar II staff for personally participating in the studies from which we obtained some of the current findings in this study, as well as the institute's academic staff for providing scientific and financial contributions to the expedition.

\section{References}

Aksu, A., Taşkın, ÖS., Çağlar, N. (2021). Müsilajın Çevresel Şartlarda Değișen Kimyasal Karakterizasyo nu. Marmara Denizi'nin Ekolojisi: Deniz Salyası Oluşumu, Etkileşimleri ve Çözüm Önerileri. Türkiye Bilimler Akademisi

Altıok, H., Kayişoğlu, M. (2015). Seasonal and interannual variability of water exchange in the Strait of Istanbul. Mediterranean Marine Science, 16(3), 644-655

Balkıs-Özdelice, N., Durmus, T., Toklu-Alicli, B., Balci, M. (2020). Phytoplankton composition related to the environmental conditions in the coastal waters of the
Gulf of Erdek, Indian Journal of Geo-Marine Sciences 49(9):1545-1559

Behzadian, M., Kazemzadeh, R. B., Albadvi, A., Aghdasi, M. (2010). PROMETHEE: A comprehensiv e literature review on methodologies and applications. European journal of Operational research, 200(1), 198-215

Besiktepe S, Sur HI, Özsoy E, Latif MA, Oğuz T, Ünlüata Ü (1994) The circulation and hydrography of the Marmara Sea. Prog Oceanogr 34:285-334

Bianchi, G. (1746). Notizie sulla vasta fioritura algale del 1729. Raccolta d'opuscoli scientifici e filologici, 34, 256-257.

Burak, S., Bilge, A. H., Ülker, D. (2021). Assessment and simulation of water transfer for the megacity Istanbul. Physical Geography, 1-25.

Cambrainha, G. M., Fontana, M. E. (2018). A multicriteria decision making approach to balance water supply-demand strategies in water supply systems. Production, 28.

Coban, A., Ertis, I. F., Cavdaroglu, N. A. (2018). Municipal solid waste management via multi-criteria decision making methods: A case study in Istanbul, Turkey. Journal of cleaner production, 180, 159-167.

Cozzi, S., Ivančić, I., Catalano, G., Djakovac, T., Degobbis, D. (2004). Dynamics of the oceanographic properties during mucilage appearance in the Northern Adriatic Sea: analysis of the 1997 event in comparison to earlier events. Journal of Marine Systems, 50(3-4), 223-241.

Danovaro, R., Umani, S. F., Pusceddu, A. (2009). Climate change and the potential spreading of marine mucilage and microbial pathogens in the Mediterranean Sea. PLoS One, 4(9), e7006.

Del Negro, P., Crevatin, E., Larato, C., Ferrari, C., Totti, C., Pompei, M., Umani, S. F. (2005). Mucilage microcosms. Science of the Total Environment, 353(1-3), 258-269

Ergül, H. A., Balkis-Ozdelice, N., Koral, M., Aksan, S., Durmus, T., Kaya, M., Kayal, M., Ekmekci, F., Canli, O. (2021). The early stage of mucilage formation in the Marmara Sea during spring 2021. Journal of the Black Sea/Mediterranean Environment, 27(2) 232-257.

Funari, E., Ade, P. (1999). Human health implications associated with mucilage in the northern Adriatic Sea. Annali dell'Istituto superiore di sanità, 35(3), 421-425.

Giani, M., Savelli, F., Berto, D., Zangrando, V., Ćosović, B., Vojvodić, V. (2005). Temporal dynamics of dissolved and particulate organic carbon in the northern Adriatic Sea in relation to the mucilage events. Science of the Total Environment. 353(1-3), 126-138.

Kavzoğlu, T., Tonbul, H., Çölkesen, İ., Sefercik, U.G. (2021). The Use of Object-Based Image Analysis for Monitoring 2021 Marine Mucilage Bloom in the Sea of Marmara. International Journal of Environment and Geoinformatics, 8(4), 529-536, doi.10. 30897/ijegeo.990875

Kraus, R., Supic, N. (2015). Sea dynamics impacts on the macroaggregates: A case study of the 1997 
mucilage event in the northern Adriatic. Progress in oceanography, 138, 249-267.

Kumar, A., Sah, B., Singh, A. R., Deng, Y., He, X., Kumar, P., Bansal, R. C. (2017). A review of multi criteria decision making (MCDM) towards sustainable renewable energy development. Renewable and Sustainable Energy Reviews, 69, 596-609.

Malej, A., Mozetič, P., Turk, V., Terzič, S., Ahel, M., Cauwet, G. (2003). Changes in particulate and dissolved organic matter in nutrient-enriched enclosures from an area influenced by mucilage: the northern Adriatic Sea. Journal of plankton research, 25(8), 949-966.

Mohammad1, M., Hosseinal1, F. (2019). Assessment and Comparison the Location of Six Universities in Tehran City Using GIS and Multi Criteria Decision Making Methods, International Journal of Environment and Geoinformatics, 6(1), 143-147, doi.10.30897/ijegeo.551753

Opricovic, S., Tzeng, G. H. (2004). Compromise solution by MCDM methods: A comparative analysis of VIKOR and TOPSIS. European journal of operational research, 156(2), 445-455.

Özalp, H. B. (2021). First massive mucilage event observed in deep waters of Çanakkale Strait (Dardanelles ), Turkey. J. Black Sea/Mediterranean Environment, 27(1), 49-66.

Öztürk, İ. D., Mutlu, S., Kaman, G., Partal, F. B., Demirtaş, A., Çağlar, S., Kuzyaka, E., Altık, H.,.Ediger, D. (2021). Vertical distribution of mucilage typology in the water column after a massive mucilage formation in the surface waters of the Sea of Marmara. Journal of the Black Sea/Mediterranean Environment, 27(2) 184-201.

Öztürk, İ., Dülekgürgen, E., Erşahin M.E. (2021). Marmara'da Deniz Salyası Sorunu: Tanımı, Sebepleri, Boyutları, Değerlendirme ve Çözüm Önerileri The Mucilage Problem in Marmara: Definition, Causes, Dimensions, Evaluation and Recommendations For Solution, Türkiye Bİlimler Akademisi.

Precali, R., Giani, M., Marini, M., Grilli, F., Ferrari, C. R., Pečar, O., Paschini, E. (2005). Mucilaginous aggregates in the northern Adriatic in the period 1999-2002: typology and distribution. Science of the Total Environment, 353(1-3), 10-23.

Rinaldi, A., Vollenweider, R. A., Montanari, G., Ferrari, C. R., Ghetti, A. (1995). Mucilages in Italian seas: the Adriatic and Tyrrhenian seas, 1988-1991. Science of the Total Environment, 165(1-3), 165-183.

Savun-Hekimoğlu, B., Erbay, B., Hekimoğlu, M., Burak, S. (2021). Evaluation of water supply alternatives for Istanbul using forecasting and multi-criteria decision making methods. Journal of Cleaner Production, 287, 125080.

Savun-Hekimoğlu, B., Gazioğlu, C. (2021). Mucilage Problem in the Semi-Enclosed Seas: Recent Outbreak in the Sea of Marmara. International Journal of Environment and Geoinformatics, 8(4), 402-413.
Scholten, L., Schuwirth, N., Reichert, P., Lienert, J. (2015). Tackling uncertainty in multi-criteria decision analysis-An application to water supply infrastructure planning. European journal of operational research, 242(1), 243-260.

Sulemana, A., Forkuo, E. K., Arthur, E. T., Agyeigyamfi, K., Otchere-darko, E., Ayaim, M. K. (2020). Multi-Criteria Selection of Suitable Institutional Solid Waste Collection Sites: A Case of KNUST Campus, Kumasi, Ghana. International Journal of Environment and Geoinformatics, 7(3), 372-380, doi.10.30897/ijegeo.696335

Topçu, N. E., Öztürk, B. (2021). The impact of the massive mucilage outbreak in the Sea of Marmara on gorgonians of Prince Islands: A qualitative assessment. J. Black Sea/Mediterranean Environment 27(2), 270-278.

Uğur, A., Yılmaz, O.S., Çelen, M., Ateş, A.M., Gülgen, F., Şanl, F.B. (2021). Determination of mucilage in the Sea of Marmara using remote sensing techniques with google earth engine. International Journal of Environment and Geoinformatics, 8(4), 423-434.

Umani, S. F., Ghirardelli, E., Specchi, M. (1989). Gli episodi di" mare sporco" nell'Adriatico dal 1729 ai giorni nostri. Ufficio stampa e pubbliche relazioni della Regione Friuli-Venezia Giulia. 


\section{APPENDIX: Questionnaire}

\section{Criteria}

Indicate the importance of the criteria given in Table 1 by using the expressions given on the scale below.

Importance: Very High (VH), High (H), Slightly High (SH), Medium, Slightly Low (SL), Low (L), Very Low (VL)

Table 1. Importance of Evaluation Criteria

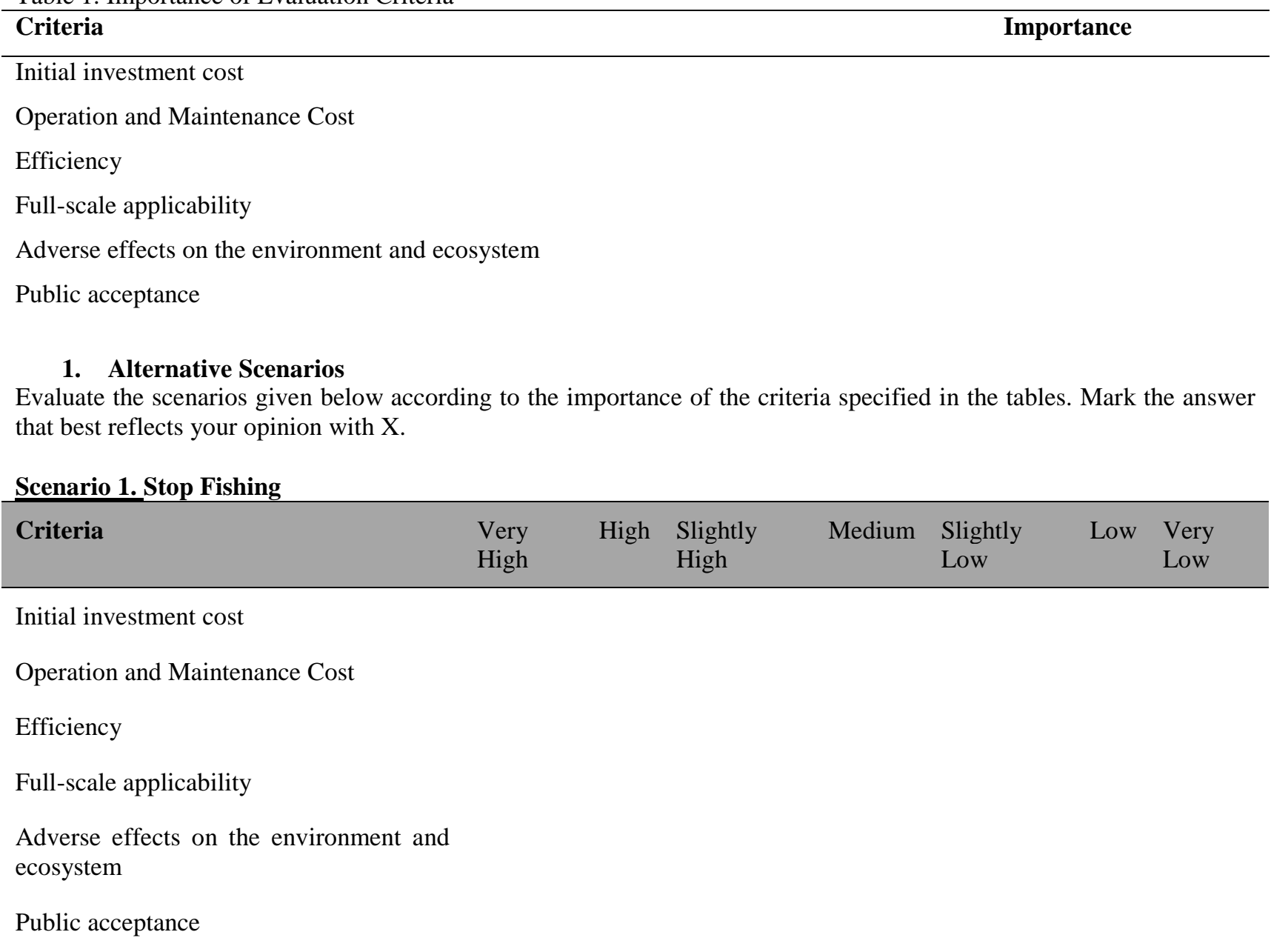

Scenario 2. Eliminating mucilage with beneficial bacteria

\begin{tabular}{lllllll}
\hline Criteria & Very & High & Slightly \\
& High & & Migh & Medium & Slightly & Low \\
Low & Very \\
\end{tabular}

Initial investment cost

Operation and Maintenance Cost

Efficiency

Full-scale applicability

Adverse effects on the environment and ecosystem

Public acceptance 
Scenario 3. Reactive oxygen dosing

\begin{tabular}{lllllll}
\hline Criteria & Very & High & Slightly \\
& High & & High & Medium & Slightly & Low Very \\
& & & Low & Low
\end{tabular}

Initial investment cost

Operation and Maintenance Cost

Efficiency

Full-scale applicability

Adverse effects on the environment and ecosystem

Public acceptance

Scenario 4. Collecting mucilage on the surface

$\begin{array}{llllllll}\text { Criteria } & \text { Very } & \text { High } & \text { Slightly } \\ \text { High } & & \text { High } & \text { Medium } & \text { Slightly } & \text { Low } & \text { Very } \\ \text { Low } & & & \end{array}$

Initial investment cost

Operation and Maintenance Cost

Efficiency

Full-scale applicability

Adverse effects on the environment and ecosystem

Public acceptance 